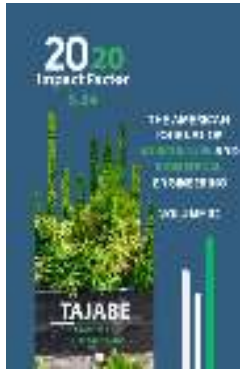

Journal Website: http://usajournalshub.c om/index,php/tajabe

Copyright: Original content from this work may be used under the terms of the creative commons attributes 4.0 licence.

\section{Some Aspects Of The Formation Of Agricultural Clusters In The Republic Of Uzbekistan}

\author{
Kamoliddin Ikromiddinovich Sirojiddinov \\ Namangan State University, Uzbekistan \\ Rustam Narzullaevich Imomov \\ Namangan State University, Uzbekistan
}

\title{
ABSTRACT
}

The article analyzes the economic content and features of the organization of agricultural clusters in Uzbekistan. The initial stage of their development in the country is investigated.

\section{KEYWORDS}

Agrocluster, agritourism, agromarketing, agro-industrial cluster

\section{INTRODUCTION}

Socio-economic progress determines the formation of new economic systems and filling the old with new content. As a result of consistently carried out reforms in agriculture, there are economic entities with a new organizational structure. One of them is agricultural clusters, and in developed countries this business structure functions in a very successful way. Agrocluster in the general sense means the joint functioning of a number of economic entities in the 
agricultural sector on the basis of mutually beneficial cooperation.

Three specific properties of agroclusters can be conventionally distinguished:

- Territorial specialization and localization of production of agricultural products of a certain type;

- Establishment in the industry of mutual economic ties between various industries for production, sale

Storage and processing of agricultural products.

\section{THE MAIN FINDINGS AND RESULTS}

The organization of agricultural clusters is due to the need to mitigate the negative consequences of high risks typical for the activities of the agricultural sector, the availability of real opportunities for optimal quantitative distribution between the participants in the general technological chain of production and delivery to consumers. In this area, countries with highly developed economies have accumulated quite a lot of experience and a high efficiency of the agricultural sector is achieved. The study of such experience and its implementation in Uzbekistan contributes to a positive solution to the most acute problems of ensuring food security without prejudice to the economic interests of economic entities, while ensuring high efficiency of production and processing.

In the system of agricultural clusters, processing enterprises, on the basis of a cooperation agreement, can unite around themselves agricultural producers, including owners of household plots, farms and dekhkan farms, cooperatives, agricultural firms, research institutions that provide various services, infrastructure institutions, trade enterprises, advertising and marketing service. The large number and rather narrow specialization of the participants, on the one hand, ensure the diversification of general activities, and on the other hand, high efficiency of certain types of activities.

Agroclusters can be organized on a joint or separate initiative of local government authorities (district khokimiyat), agricultural producers (owners of household plots, farms and dekhkan farms, etc.) and processing enterprises. One of the important features of such education is the general joint activity of the participants based on mutual trust and respect. This activity includes the cultivation of crops, processing, sale, storage and research processes. In most cases, it is characterized by the implementation of large investment projects. 


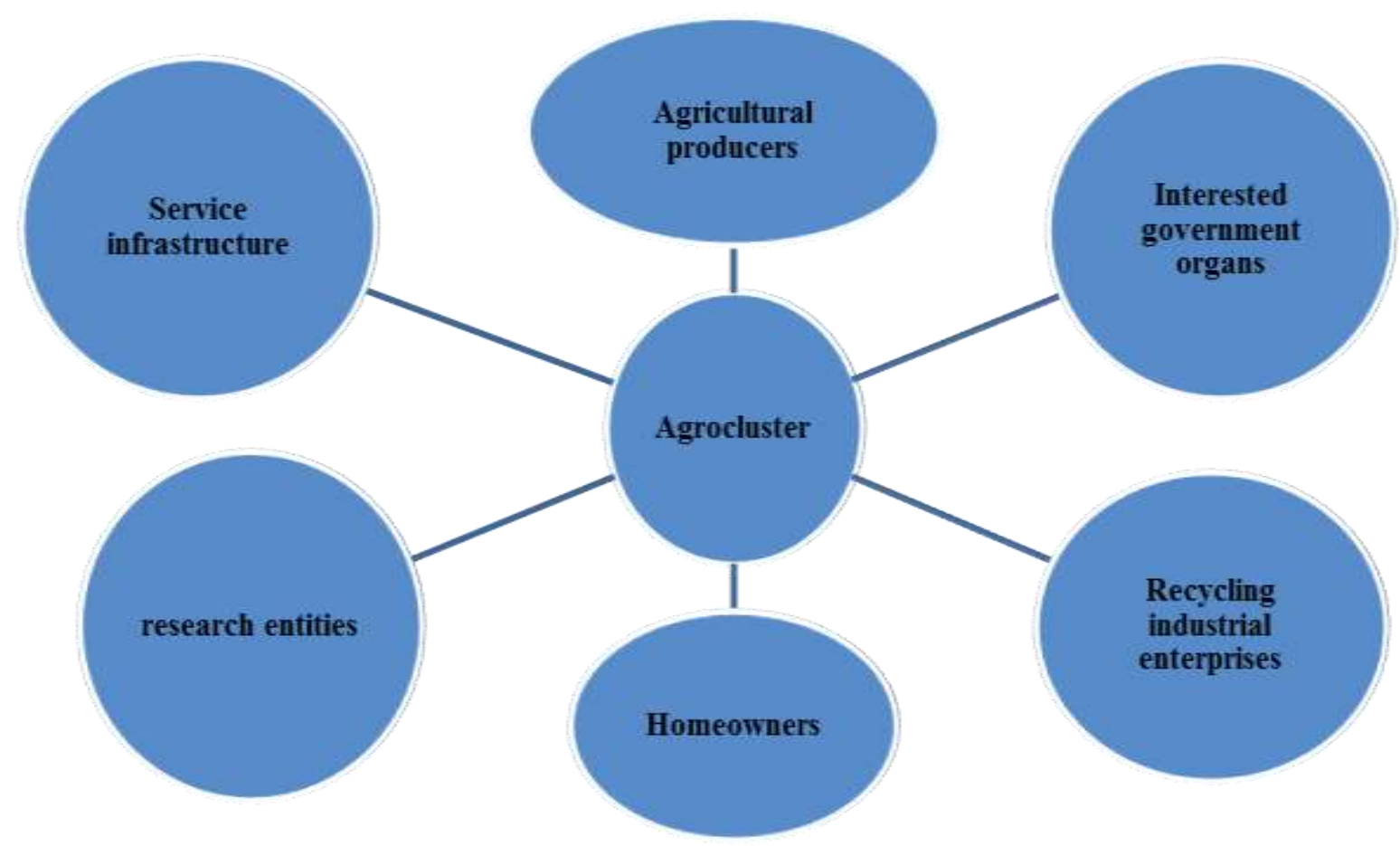

Picture 1. Internal links of agro-cluster education.

The processes of agroclusterization in the developed and rapidly developing countries of the world began long enough and quickly showed their effectiveness. For example, in the Republic of Korea, such measures were carried out with the aim of stabilizing and improving the demographic situation in the countryside (reducing the outflow of the rural population, especially young people, to cities in search of work). To support production systems formed by historical traditions, bringing industry and agritourism into the village. In particular, the Suchang agro-cluster is operated by local government bodies. It has established the production of various products from soybeans, peppers, strawberries and plums. The agro-cluster includes 5,292 farms with a sown area of 9,780 hectares and 12,331 employees. Scientific research occupies an important place in the cluster. This territory is home to 30 thousand people. The territory's export volumes a year on average amount to USD 1 million. There are opportunities for the development of agritourism and hotel service. Due to the development of two directions in 2018, it was planned to bring exports to 3 million US dollars. It is noteworthy that 12,000 tourists visit this settlement annually.

Uzbekistan, the experience of this cluster can be applied: to support programs for the development of rural areas, in the fermentation of products such as soybeans, peppers and others based on historical 
traditions, in preserving family businesses and houses in their original form and turning them into tourism objects, in organizing agritourism (participation of townspeople and children in their own hand picking of fruits and vegetables, in their processing) in establishing a hotel business in the countryside, holding festivals and other events.

In the Republic of Korea, scientific achievements are widely used in the organization of clusters. In agricultural clusters, there are separate links for seed production, testing of new varieties, marketing research, and information support. We are convinced that the application of the experience of Korea in Uzbekistan will give significant positive results.

World experience shows that when organizing clusters, it is necessary to pay attention to the following points:

- The important place of the state in financial support of agriculture and its leading role in the implementation of reforms;

- Striving for the maximum possible preservation of historical monuments and national traditions, values and customs, the development of agritourism, food tourism and hotel services based on the modernization of these values;

- Territorial specialization, increasing the competitiveness of agricultural products and ensuring sustainable development of production;

- Creation of conditions for the direct application of scientific achievements of researchers of scientific institutions and higher educational institutions;

- Financial support for scientific research in the field of agriculture at the level of state policy;
- The desire to organize production on the basis of innovation, the creation (formation) of an effective mechanism for their support;

- Development of the agromarketing system, assistance and participation of state organizations of marketing services;

- Training of personnel, special attention to human capital and its development in the countryside.

By their economic essence, agricultural clusters can function successfully only on a market basis, widely using material incentives, with real economic freedom of producers, without infringing on their rights. At the same time, market mechanisms are most effective with constant technical and technological renewal of production, with constant implementation of scientific achievements.

In Uzbekistan, starting in 2017, the organization of clusters has risen at the level of state policy. Initially, they were organized in cotton growing and by 2020 this industry was decisively covered by this form of economic structures. In the clusters, we achieved a significant increase in the material interest of manufacturers of primary products. As a result, the yield of cotton has noticeably increased and the volume of production on the same land areas has increased.

In 2020, 96 cotton-growing clusters will operate in 136 regions of the country, covering 21,952 farms.

\section{CONCLUSION}

Using the possibilities of integrating research institutes into the growth points of the region, its participation in clustering processes allows 
us to reveal all the advantages and disadvantages of the marketing strategy, while both the region and research institutes can productively use their inherent strengths that other territories and enterprises lack ... Scientific and educational organizations, when entering the agro-industrial cluster, set themselves the main task - to promote the preservation and the fullest use of the scientific and technical potential of the agroindustrial complex. The inclusion of universities in agro-industrial clusters will allow it to provide an additional advantage institutional investors will be able to make investments simultaneously in the segments of the real sector of interest to them, educational and research processes.

\section{REFERENCES}

1. "On the Strategy of Actions for the Further Development of the Republic of Uzbekistan". Decree of the President of the Republic of Uzbekistan, February 7, 2017. - The People's Word, February 8, 2017.

2. Decree of the President of the Republic of Uzbekistan "On measures to further ensure the country's food security." http://www.lex.uz/ -

3. Sirozhiddinov I.K., Botirova R.A. Opportunities for the development of export of fruits and vegetables in the region. - Actual challenges of modern science. Collection of scientific papers. Issue 11 (31). Part I // PereyaslavKhmelnitsky, 2018.S. $82-85$.

4. Sirozhiddinov I.K., Botirova R.A. Opportunities for the development of export of fruits and vegetables in the Namangan region. - Young scientist, No. 50, 2018. P. $174-176$. 